\title{
Earnings quality measures and excess returns: A case study of Tehran Stock Exchange
}

\author{
Hassan Hemmati ${ }^{\mathrm{a}}$ and Seyed Ali Sayadi ${ }^{\mathbf{b}^{*}}$
}

${ }^{a}$ Assist. Prof. \& Faculty Member, Department of Accounting, Raja University, Qazvin, Iran ${ }^{b}$ M.Sc. Student, Department of Accounting, Kashan Branch, Islamic Azad University (IAU), Kashan, Iran

C H R O N I C L E

Article history:

Received December 1, 2012

Received in revised format

2 March 2013

Accepted 10 March 2013

Available online

March 112013

Keywords:

Earning quality

Excess return

Tehran Stock Exchange

\section{A B S T R A C T}

This paper presents an empirical investigation to study the relationship between earning quality measure and excess returns on selected firms trading on Tehran Stock Exchange. The purpose of this study is to find the relative advantage of income figures reported in formal financial statements. The study uses hedge return, six accounting ratios and three market ratios and performs the study over the period of 2001-2011 using 56 firms whose shares were traded on Tehran Stock Exchange. The proposed study uses regression analysis as well as structural equation modeling. The results of this study indicate that market based figures are more influencing than accounting based ratios on hedge return. In other words, hedge return for persistency index was more predictable than smoothness and abnormal accruals. However, on the contrary to what we expected, hedge return for accruals was not more than other accounting based figures.

\section{Introduction}

Earning quality plays an important role on making investment decisions and there are many studies to measure the effect of different accounting or market based factors on such decisions. Richardson et al. (2010) performed a comprehensive review on accounting anomalies and fundamental analysis. Fairfield et al. (2003) discussed accrued earnings and growth and investigated some implications for future profitability and market mispricing. Bartov et al. (2000) studied investor sophistication and patterns in stock returns after earnings announcements. They reported that excess returns could be a result of market mispricing and explained that because of lack of a generally accepted asset pricing model, it is difficult to detect a specific reason for potential mispricing. Mispricing could be a result of market inefficiencies or behavioral biases of investors. 
Perotti and Wagenhofer (2011) investigated the capability of eight common earnings quality measures to describe future excess returns. They rank different measures based on the size of hedge returns earned from portfolios constructed by sorting over the respective measures. They recommended that market-based measures including earnings response coefficient, value relevance are correlated with higher hedge returns than accounting-based measures based on a large sample of U.S. non-financial firms over 1988-2007. They also reported that accruals quality and abnormal accruals performed substantially better than persistence, predictability, and smoothness.

This paper presents an empirical investigation to study the relationship between earning quality measure and excess returns on selected firms trading on Tehran Stock Exchange. The organization of this paper first presents details of our proposed study adopted from the recently published work by Perotti and Wagenhofer (2011) and then uses the data gathered from Tehran stock exchange presents our findings.

\section{The proposed method}

This paper presents an empirical investigation between earning quality measure and excess returns on selected firms trading on Tehran Stock Exchange. The purpose of this study is to find the relative advantage of income figures reported in formal financial statements. The study uses hedge return, six accounting ratios and three market ratios and performs the study over the period of 2001-2011 using 56 firms whose shares were traded on Tehran Stock Exchange. In selection process, we have excluded holding firms and only selected firms whose fiscal calendar was ended March 23 . The proposed study uses regression analysis as well as structural equation modeling. The hedge return is calculated based on the method proposed by Fama and French (1993). In order to compute expected return, we use the method developed by Landsman et al. (2011). Therefore, we have,

$R_{i, t}-R_{f, t}=\alpha_{i}+\beta_{i}^{M k T}\left(R_{M, t}-R_{f, t}\right)+\beta_{i}^{S M B} S M B_{t}+\beta_{i}{ }^{H M L} H M L_{t}+\varepsilon_{i, t}$,

where $R_{i, t}$ is the actual return of firm $i, R_{f, t}$ is the risk free rate, $R_{M, t}$ is the actual return of market, $S M B t$ is the monthly return on the size factor mimicking portfolio, $H M L t$ the monthly return on the book-to-market factor mimicking portfolio and $U M D t$ is the monthly return of the momentum factor mimicking portfolio. Taking these estimated item $\beta$ 's for month $t$ as expected $\beta$ 's for month $t+1$ we measure the expected risk-adjusted return based on the following relationship,

$\mathrm{E}\left[\mathrm{R}_{\mathrm{i}, \mathrm{t}+1}\right]=\mathrm{R}_{\mathrm{f}, \mathrm{t}+1}+\beta_{\mathrm{i}}^{\mathrm{MkT}}\left(\mathrm{R}_{\mathrm{M}, \mathrm{t}+1}-\mathrm{R}_{\mathrm{f}, \mathrm{t}+1}\right)+\beta_{\mathrm{i}}^{\mathrm{SMB}} \mathrm{SMB}_{\mathrm{t}+1}+\beta_{\mathrm{i}}{ }^{\mathrm{HML}} \mathrm{HML}_{\mathrm{t}+1}+\varepsilon_{i, t}$

where the factor returns in $t+1$ are calculated as each factor's average monthly return over the previous 36 months. The excess return of each company and month is the actual return minus the expected return as follows,

$E X R E T_{i, t}=R_{i, t}-E\left[R_{i, t}\right]$

where EXRETi,t is the month $t$ percentage excess return on the stock of company $i$. The proposed study of this paper used the method originally developed by Perotti and Wagenhofer (2011) except we use quarterly information. The proposed study of this paper calculates earning quality (EQ) based on the proposed model presented by Dechow et al. (2010), Schipper and Vincent (2003) and Francis et al. (2004) as follows,

$A C C=\triangle C A-\triangle C L-\triangle C A S H+\triangle S T D E B T-D E P R$,

where total accrual $(A C C)$ is calculated based on change in current asset $(C A)$, change in current liabilities $(C L)$, change in cash, changes in short term debt (STDEBT) and depreciation (DEPR). 
Persistency is another ratio, which shows how reliable an earning is over the long term and it is calculated based on the method proposed by Perotti and Wagenhofer (2011) as follows,

$N I B E_{I, t}=\alpha+\beta N I B E_{i, t-1}+\varepsilon_{i, t}$

where NIBE is scaled by total assets at the beginning of period $t$ and $\alpha$ and $\beta$ are coefficient to be estimated. Predictability is another measure, which is equal to adjusted $\mathrm{R}^{2}$ computed in the implementation of Eq. (5). The first smoothness measure (EQ3) is the ratio of the standard deviation of earnings over the standard deviation of cash flow from operations, which is calculated as follows,

$\sigma\left(N I B E_{i, t}\right) / \sigma\left(C F O_{i, t}\right)$

where $N I B E$ and $C F O$ are scaled based on total assets at the beginning of period $t$. The second smoothness measure (EQ4) is calculated based on the correlation of accruals and cash flow from operations,

$\rho\left(A C C_{i, t}, C F O_{i, t}\right)$

where $A C C$ and $C F O$ are scaled by total assets at the beginning of period $t$. Another set of earnings quality measures, abnormal accruals and accruals quality, concentrate on accruals and tries to capture earnings management. Abnormal accruals (EQ5) are calculated as follows,

$A C C_{i, t}=\alpha+\beta_{1}\left(\Delta R E V_{i, t^{-}} \Delta A R_{i, t}\right)+\beta_{2} P P E_{i, t}+\varepsilon_{i, t}$

where $\triangle R E V$ is the change in revenues, $\triangle A R$ the change in accounts receivable, and $P P E$ includes fixed assets and all variables are scaled by total assets at the beginning of period $t$. Accruals Quality is also evaluated using the following relationship,

$C A C C_{i, t}=\alpha+\beta_{1} C F O_{i, t-1}+\beta_{2} C F O_{i, t}+\beta_{3} C F O_{i, t+1}+\varepsilon_{i, t}$

where variables are scaled by total assets at the beginning of period $t$. Finally, the two value relevance measures are estimated using the following,

$R E T_{i, t}=\alpha+\beta N I B E_{i, t} / p_{i, t}+\varepsilon_{i, t}$

where RET represents the 12-month return ending three months after the end of the fiscal year, and $P$ represents the market value of equity at the beginning of period $t$. The first measure (EQ7) is the earnings response coefficient (ERC), which is the $\beta$ in (10). The second measure (EQ8) is equal to $\mathrm{R}^{2}$ in Eq. (10) and the third one is calculated based on the following regression technique,

$\left(E R C_{i, t}\right)^{2} \cdot \operatorname{Var}\left(N I B E_{i, \ell}\right)$

The proposed study of this paper examines the following three hypotheses,

1. Hedge returns are higher for market-based measures than for the accounting-based measures studied.

2. Hedge returns are higher for persistency-based measures than for the non-accrual and smoothness measures studied.

3. Hedge returns are higher for accruals measures than for other accounting-based measures. 
The proposed study of this paper uses the following conceptual model to verify the hypotheses of the survey.

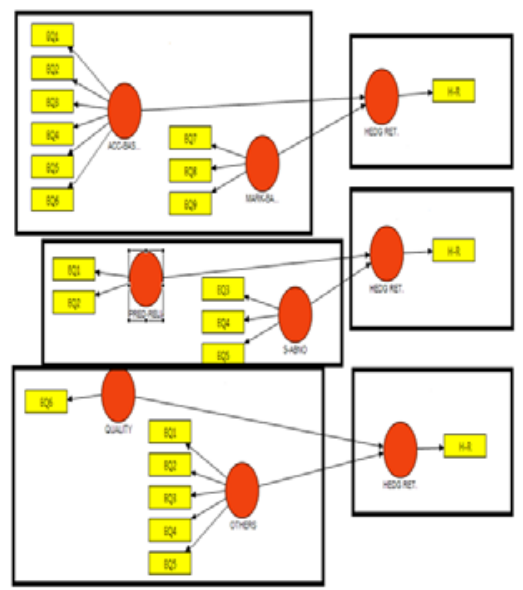

Fig. 1. The proposed framework of the conceptual study

\section{The results}

In this section, we present details of our findings on three hypotheses of the survey.

\subsection{Measurability}

\subsubsection{Unidimensionality criteria}

In terms of Unidimensionality criteria, the results for the first hypothesis were on average for EQ1, EQ7, EQ8, they were on high level for EQ2, EQ3, EQ5 and EQ6. Finally, the results were strongly high level for EQ4 and EQ9. For the second hypothesis, the result of Unidimensionality criteria was strong for EQ2, EQ3, EQ5 and they were very strong for EQ4 and EQ1. Finally, for the third hypothesis, we have reached strong evidences for EQ1, EQ2, EQ3, EQ4, EQ5 and EQ6.

\subsubsection{Cronbach alpha}

For the first hypothesis, Cronbach alpha (Cronbach, 1951) were calculated as 0.67233 for accounting based ratio, 1 for hedge return and 0.6154 for market based ratio. For the second hypothesis, Cronbach alpha were calculated as 0.5301 for the persistency, 1 for hedge return and it was calculated as 0.64187 for nonaccrual item. Finally, for the third hypothesis, Cronbach alpha was calculated as 1 for accrual quality and hedge return and 0.6766 for other accounting ratios.

\subsubsection{Composite reliability}

For the first hypothesis, composite reliability were calculated as 0.68333 for accounting based ratio, 1 for hedge return and 0.7531 for market based ratio. For the second hypothesis, composite reliability were calculated as 0.7521 for the persistency, 1 for hedge return and it was calculated as 0.6072 for nonaccrual item. Finally, for the third hypothesis, composite reliability was calculated as 1 for accrual quality and hedge return and 0.6913 for other accounting ratios.

\subsubsection{Average Variance Extracted}

For the first hypothesis, average variance extracted (AVE) were calculated as 0.6967 for accounting based ratio, 1 for hedge return and 0.53438 for market based ratio. For the second hypothesis, AVE 
were calculated as 0.5476 for the persistency, 1 for hedge return and it was calculated as 0.5222 for nonaccrual item. Finally, for the third hypothesis, AVE was calculated as 1 for accrual quality and hedge return and 0.5267 for other accounting ratios.

\subsubsection{Discriminant Validity}

For the first hypothesis, discriminant validity were calculated as 0.8346 for accounting based ratio, 0.2089 for hedge return and 0.278 for market based ratio. For the second hypothesis, discriminant validity were calculated as 0.74 for the persistency, 0.172 for hedge return and it was calculated as 0.1027 for nonaccrual item. Finally, for the third hypothesis, Discriminant Validity was calculated as 0.0647 for accrual quality, 1 for hedge return and 0.203 for other accounting ratios.

\subsection{Validation of structural equation modeling}

\subsubsection{The results of $R$-Square}

The results of coefficient of determination for the first, the second and the third hypotheses were $0.3786,0.5321$ and 0.7014 , respectively. As we can observe the results were relatively weak for the first hypothesis, on average for the second hypothesis and it was relatively strong for third hypothesis.

\subsubsection{Path Coefficients}

For the first hypothesis, the ratios of path coefficients were 1.7901 and 2.2776 for accounting based and marketing based figures, respectively. In terms of the first hypothesis, the ratios of path coefficients were 1.743 and 4.02301 for accounting based and marketing based figures, respectively. Finally, the ratios of path coefficients were 1.7031 and 3.4973 for accounting based and marketing based figures, respectively.

\subsubsection{Predictive Relevance}

For the first hypothesis, predictive relevance were calculated as 0.002976 for accounting based ratio, 0.017857 for hedge return and 0.011904 for market based ratio. For the second hypothesis, predictive relevance were calculated as 0.1575 for the persistency, 0.0179 for hedge return and it was calculated as 0.0268 for nonaccrual item. Finally, for the third hypothesis, predictive relevance was calculated as 0.0893 for accrual quality, 0.0178 for hedge return and 0.02143 for other accounting ratios.

Based on the results, we can conclude that market based figures are more influencing than accounting based ratios on hedge return. In other words, hedge return for persistency index was more predictable than smoothness and abnormal accruals. However, on the contrary to what we expected, hedge return for accruals was not more than other accounting based figures.

\section{Conclusion}

In this paper, we have adopted a study by Perotti and Wagenhofer (2011) to investigate the relationship between earning quality measure and excess returns on selected firms trading on Tehran Stock Exchange. The study was performed based on hedge return, six accounting ratios and three market ratios and performed the study over the period of 2001-2011 using 56 firms whose shares were traded on Tehran Stock Exchange. The proposed study used regression analysis as well as structural equation modeling. The results of this study have indicated that market based figures were more influencing than accounting based ratios on hedge return. In other words, hedge return for persistency index was more predictable than smoothness and abnormal accruals. However, on the 
contrary to what we expected, hedge return for accruals was not more than other accounting based figures

\section{References}

Bartov, E., Radhakrishnan, S. \& Krinksy, I. (2000). Investor sophistication and patterns in stock returns after earnings announcements. The Accounting Review, 75, 43-63.

Cronbach, L. J. (1951). Coefficient alpha and the internal structure of tests. Psychometrika, 16(3), 297-334.

Dechow, P.M., Ge, W., \& Schrand, K.M. (2010). Understanding earnings quality: A review of the proxies, Their determinants and their consequences. Journal of Accounting and Economics, 50, 344-401.

Fama, E. F., \& French, K. R. (1993). Common risk factors in the returns on stocks and bonds. Journal of financial economics, 33(1), 3-56.

Fairfield, P. M., Whisenant, S., \& Lombardi Yohn, T. (2003). Accrued earnings and growth: Implications for future profitability and market mispricing. The Accounting Review, 78, 353-371.

Francis, J., LaFond, R., Olsson, P.M., \& Schipper, K. (2004). Costs of equity and earnings attributes. The Accounting Review, 79, 967-1010.

Landsman, W. R., Miller, B. L., Peasnell, K., \& Yeh, S. (2011). Do investors understand really dirty surplus?. The Accounting Review, 86(1), 237-258.

Perotti, P. \& Wagenhofer, A. (2011). Earnings quality measures and excess returns. University of Graz.

Richardson, S., Tuna, I., \& Wysocki, P. (2010). Accounting anomalies and fundamental analysis: A review of recent research advances. Journal of Accounting and Economics, 50, 410-454.

Schipper, K., \& Vincent, L. (2003). Earnings quality. Accounting Horizons, 17, 97-110. 